\title{
夏季における住まい手の熱環境調整の行動と温冷感に関する観察方法の研究 STUDY ON A METHOD TO OBSERVE THE BEHAVIORAL PATTERNS AND THERMAL SENSATIONS OF OCCUPANTS PROVIDED WITH PASSIVE AND ACTIVE COOLING STRATEGIES UNDER ACTUAL LIVING CONDITIONS
}

高橋達*1, 斉藤雅也*2, 蟻川洋祐*3, 杉岡弘朗*4 松岡弘幸*5, 宿谷昌則*6

Itaru TAKAHASHI, Masaya SAITO, Yousuke ARIKAWA, Hiroaki SUGIOKA, Hiroyuki MATSUOKA and Masanori SHUKUYA

\begin{abstract}
We made a series of subjective experiment for understanding the relationships between various cooling strategies such as cross ventilation, the use of small fans, the use of air conditioners, various behavioral patterns such as the choices of cooler paths approaching to the building in question, the change of clothes, and thermal sensations. The votes and behaviors of the subjects were recorded by video cameras so that the subjects were not forced to answer simplified single-scaled questionnaires and their behavioral patterns, which should be found in actual thermal environment, are not distorted. It was found that most of the subjects in a naturally-ventilated room were very sensitive to the fluctuation of the air current in the given thermal environment and at the same time very active in having coolness. It does not necessarily require lower temperature provided that the subjects reach the room walking in from the cooler outdoor environment. In the case of the set point temperature of $25^{\circ} \mathrm{C}$, the subjects wearing ties felt cool and comfortable, though the subjects wearing no ties felt cold and uncomfortable. In other words, it is possible that wearing no ties enables the subjects to feel cool enough and comfortable with higher set-point temperature.
\end{abstract}

keywords : thermal sensation, behavior, observation, natural ventilation, air conditioning, outdoor thermal environment 温冷感、行動、観察、通風、冷房、屋外熱環境

\section{1.はじめに}

ここ数年、環境問題への関心の高まりに後押しされて、総数は

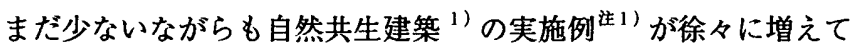
きている。自然共生建築が計画され建設された後に、その機能が 十分に働くには、個々のパッシブ手法の物理的作用に加えて、建 築環境に対する住まい手の積極的な働きかけが必要であり、それ らの相互作用によって環境保全と豊かな住生活の双方が実現され ることになる。自然共生建築は、建築環境と住まい手を含んだ全 体として機能し活動するものと筆者らは考える。例えば、住まい 手自身が窓を開け通風を行なう場合に、空調機によって自動的に 部屋が冷やされるのとは異なる快適感が得られるのは、以上のよ うなことによると考えられる。

建築環境の快適性とは、住まい手にとっての快適性のことであ り、それは住まい手自身が建築環境を内発的に評価する、言い換 えると愛着をもつことによって決定されるものである ${ }^{122) 3 。 ~}$ のことは、住まい手の能動的な行動や体感とパッシブ手法の物理 的効果との関係を調查するには、普段の生活に近い状況をつくっ て住まい手の内発的な鮮きかけをできるだけ抽き出せるようにし なければならないことを意味する。何故なら実験の条件を人工的 にしていけばしていくほど、住まい手の自然な行動·感覚は把握し

\section{にくくなるはずだからである。}

岩村は深沢環境共生住宅を計画するにあたって、住まい手達と の定期的な井戸端会議の場で、住まい手が認識してきた住環境に ついて住まい手の話しを抽き出すことを試みている ${ }^{4)}$ 。そのこと を参考にして、つくり手の一方的な押し付けではない、住まい手 の内発性と地域の自然のポテンシャルを活かした家づくりを行 なっている。また、延藤は、住民参加の住まいや環境づくりには、 住まい手の住環境に対する愛着、内発性を育むプロセスが必要で あることを指摘している5)。このようなプロセスを経て形成され る自然共生建築の熱環境が住まい手にとってどのような空間とし て感じられるかを調查するには、その方法が住まい手の建築環境 に対する内発的な評価、積極的な働きかけをできるだけ阻害しな いものである必要がある。

これまで、人工気候室で被験者実験を行なう数々の研究によっ て、数多くの貴重な知見が得られている。しかしながら、現実の 建築で普段の生活を行なっている場合と、人工気候室での実験と では、在室者の行動や建築環境の評価に差が生じることが十分予 想される。したがって、人工気候室での被験者実験による検討に 加え、普段の生活に近い条件下での温冷感評価・行動についても 新たに観察結果を呈示することは、つくり手側からの熱環境評価

\footnotetext{
*1 武藏工業大学大学院工学研究科建築学専攻 客貝研究員・博士 (工学)

*2 武蔵工業大学大学院工学研究科建築学専攻 客員研究員 · 博士 (工学)

*3 高砂熱学工業(侏) 職貝 (当時武蔵工業大学建築学科 大学生)

*4 タイダン侏) 職員 (当時武蔵工業大学建築学科 大学生)

*5 都市基盤公団 職員 $\cdot$ 修士 (工学) (当時武蔵工業大学 大学院生)

*6 武蔵工業大学大学院工学研究科建築学専攻 教授・工博
}

Visiting Scientist, Graduate School, Musashi Institute of Technology, Dr. Eng.

Visiting Scientist, Graduate School, Musashi Institute of Technology, Dr. Eng.

Takasago Thermal Engineering Co. Ltd.

Dai-dan Co. Ltd.

Urban Development Co., M. Eng.

Prof., Graduate School, Musashi Institute of Technology, Dr. Eng. 
だけではなく、住まい手に近い立場からの評価結果を得ることに なると考える。

夏期に暑さへ対処するためのパッシプな方法には、通風や日射 遮へいのような建築的工夫だけでなく、薄着になること、より涼 しい入室経路を選ふことことといった熟環境調整のための行動も 含まれると考える。これらの暑さへの対処法と在室者の温冷感と の関係について論じた既往の研究は少なからずある。通風に関し ては、例えば、棉原・石井・片山らの研究 ${ }^{6)}$ 、芥川・荒谷らの研 究 $^{7)}$ 、Busch の研究 ${ }^{8)}$ があり、入室に至るまでの屋外環境の影響 については、石野・佐々木らの研究 ${ }^{9)}$ 、Jitkhajornwanich らの研究

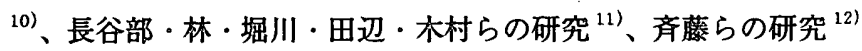
がある。着衣の重要性については、例えば田辺が実験的検討を行 なっている ${ }^{13)}$ 。しかし、住まい手の能動的な働学かけが十分に行 われるような、普段の生活とあまり変わらない条件下での温冷感 と行動の関係については、筆者らの知る限りでは研究例がない。 したがって、新たに検討を行なう必要があると考える。

本研究では、以上のことから自然共生建築にふさわしい住まい 方・熟環境とは何かを明らかにするために、暑さへのさまざまな 对処法に対応した温冷感と行動の特性を把握する方法を見出すこ とを目的とした。本研究で取り上げた方法は、被験者の温冷感申 告や行動をできるだけ自然に近い状態で把握するためにピデオ撮影 を用いるものである。申告用紙に一元化した尺度の申告を記入する 方法では、記入行為そのものが被験者の行動になんらかの制約を与 える可能胜があるという問題や、用意した項目以外の行動や温冷感 を記録できないという問題があるが、ビデオ撮影ではこれらのこ とを回避できると考えたからである。観察結果を整理するにあた り統計処理はあえて行なわず、被験者の行動や温冷感の微妙な違 いを考勴するようにした。

\section{2. 抜験者実験の概要}

実験には、横浜市都筑区にある武蔵工業大学・環境情報学部の 講義研究棟 4 階南側の二つの研究室（S 研究室・Y 研究室）を使 用した。図 1 に研究室の平面を示す。この建物の外壁には厚さ $20 \mathrm{~mm}$ の断熱材が室内㑡に取り付けられている。研究室には、外 壁に開閉可能な複層ガラス宏と、廊下に面したドアの上部に換気 空があり、通風経路が確保されている。なお、ガラス悹の開口寸 法は $0.75 \mathrm{~m} \times 1.25 \mathrm{~m}$ 、廊下側ドアの開口寸法は $0.85 \mathrm{~m} \times 2.5 \mathrm{~m}$ であ る。空の上部には、亁の出が $80 \mathrm{~cm}$ の庇が取り付けられている。

計測項目のうち、空気温度・グロープ温度・吹き出し空気温度・ 表面温度 (壁・床・天井・空) ・相対湿度は 1 分間隔で、風速は 1 秒間隔で計測した。なお講義研究棟屋上では外気温湿度・日射量・ 風向・風速を 1 分間隔で計測した。また、被験者の皮期温の変化 を把握するために入室直後・入室 30 分後・入室 60 分後（退室直 前）において、三つの実験室で被験者の熱画像を赤外線放射カメ ラにより撮影した。皮虔温を熱電対ではなく赤外線放射カメラで 計測したのは、䱉電対を皮图に貼付けると、被験者の自然な行動 や感覚が阻害される可能性があると考えたためである。

赛験は、1998年 8 月 18 日 20日の 3 日間、各日ともに $12: 30$ 〜 13:30と 14:00〜15:00の 1 日 2 回行なった。表 1 に被験者

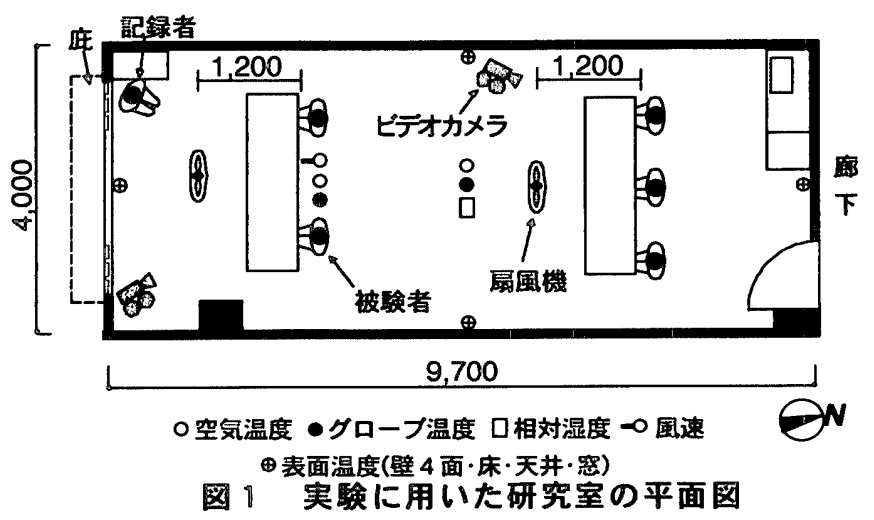

表 1 実倹パターン

\begin{tabular}{|c|c|c|c|c|c|c|}
\hline \multirow{2}{*}{ 時 } & \multicolumn{2}{|c|}{$8 / 18$} & \multicolumn{2}{|c|}{$8 / 19$} & \multicolumn{2}{|c|}{$8 / 20$} \\
\hline & $\begin{array}{r}12: 30 \\
13: 30 \\
\end{array}$ & $\begin{array}{c}14: 00 \\
15: 00 \\
\end{array}$ & $\begin{array}{r}12: 30 \\
13: 30 \\
\end{array}$ & $\begin{array}{c}14: 00 \\
15: 00 \\
\end{array}$ & $\begin{array}{r}12: 30 \\
13: 30 \\
\end{array}$ & $\begin{array}{r}14: 00 \\
15: 00 \\
\end{array}$ \\
\hline $\begin{array}{l}S \\
\text { 研 } \\
\text { 究 } \\
\text { 室 }\end{array}$ & 通風 & $\begin{array}{c}\text { 冷莂 } \\
\left(27^{\circ} \mathrm{C}\right) \\
3\end{array}$ & 通風 & $\begin{array}{c}\text { 冷房 } \\
\left(25^{\circ} \mathrm{C}\right)\end{array}$ & $\begin{array}{c}\text { 冷票 } \\
\left(27^{\circ} \mathrm{C}\right) \\
53\end{array}$ & $\begin{array}{c}\text { 冷票 } \\
\left(27^{\circ} \mathrm{C}\right) \\
\text { (5) }\end{array}$ \\
\hline $\begin{array}{l}Y \\
\text { 研 } \\
\text { 究 } \\
\text { 室 }\end{array}$ & $\begin{array}{l}\text { 冷房 } \\
\left(25^{\circ} \mathrm{C}\right)\end{array}$ & $\begin{array}{c}\text { 冷房 } \\
\left(25^{\circ} \mathrm{C}\right)\end{array}$ & 通風 & $\begin{array}{c}\text { 冷房 } \\
\left(25^{\circ} \mathrm{C}\right)\end{array}$ & $\begin{array}{l}\text { 冷房 } \\
\left(25^{\circ} \mathrm{C}\right)\end{array}$ & $\begin{array}{l}\text { 冷崖 } \\
\left(25^{\circ} \mathrm{C}\right)\end{array}$ \\
\hline
\end{tabular}

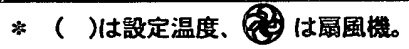

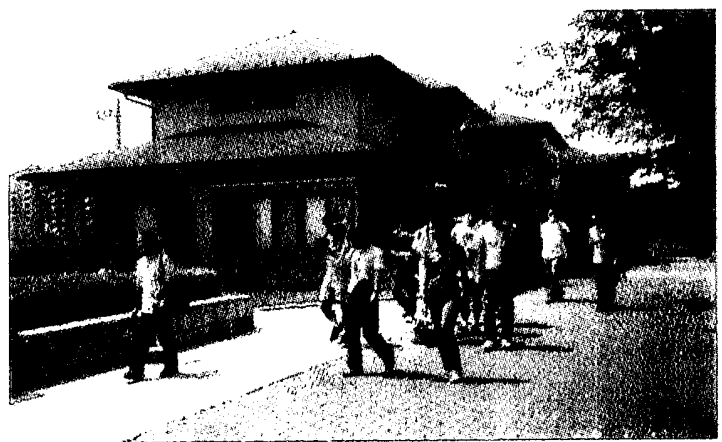

写真 1 被䀫者実検の様子（屋外移動中。左加ら 2 番目の短 パン姿の嘼録者がピデカメラで被験者たちの行動・発言を町録 している。

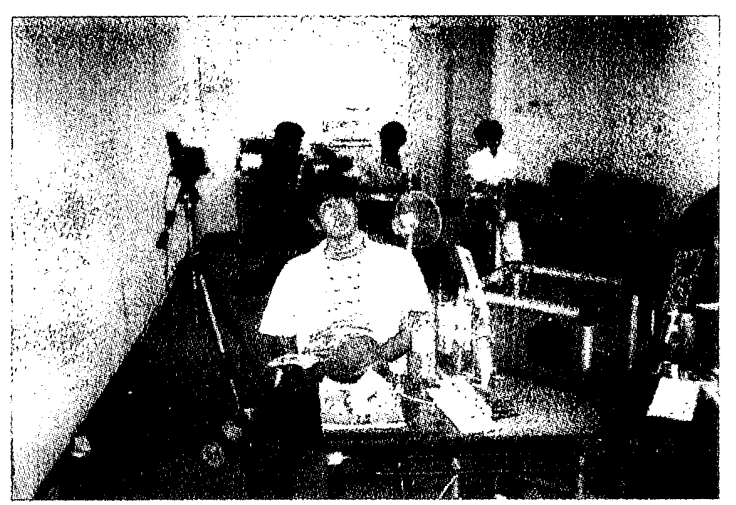

写真 2 被験者実験の様子(冷房 $\left(25^{\circ} \mathrm{C}\right)$ 空内。左の壁血に はピデオメラ、机の上には申告札のささったペットホトルや、 雑誌があ。後ろの被験者は談笑している。)

実験のパターンを示す。実験パターンは、18 日では通風・冷房の

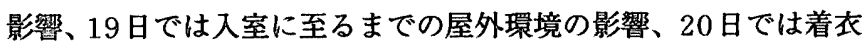
の影響について検討するように計画した。なお、普段の生活に近 
い状態を再現するために、冷房は設定温度を例えば $25^{\circ} \mathrm{C}$ 、あるい は $27^{\circ} \mathrm{C} に し て$ 行ない、実現される室温は成り行きに任せた。

被験者は二つの研究室にそれぞれ 5 人ずつ入室した。実験に参 加した被験者の延へ人数 60 人のうち 11 人は女性であり、残りが 男性であった。延べ 60 人の参加者のうち 12 人は、 3 日間のうち 2 日間参加した。なお、連続した単調な実験の繰り返しにより被 験者の内発性が損なわれないように、3 日間連続の参加は依頼せ ず、2 日連続で参加した被験者には日毎に異なる室に入室しても らっだ。

被験者は武藏工業大学の学生で年齢は 18～23 歳である。服装 は男女ともに大学での普段着と思われる半袖シャツと長スボンに 統一した。着衣量は $0.6 \mathrm{clo}$ 程度である。ただし、20日の 1 回目 $\mathrm{Y}$ 研究室では 5 人のうち 2 人の男性、 2 回目 $\mathrm{S}$ 研究室では 3 人の 男性にネクタイを着用してもらった。なお、入室に至るまでの 30 分間は、19日のS研究室を除き、比較的暑いと思われる人工舗装 面のある写真 1 のような屋外環境を必ず歩くようにした。19日に S研究室に入る被験者だけは、比較的涼しいと思われる、キャンパ ス内にある雑木林治いの遊歩道を歩いてもらった。入室前 30 分間 の平均代謝量は、どの実験パターンでも 2 met 程度である。

なお、通風の実験を行なっているときは、研究室のガラス葖・ 換気空・ドアと、4 階廊下の窓 ${ }^{14)}$ をすべて開放した。また、すべ ての実験パターンにおいて電灯照明は消してある。

写真 2 に被験者実験の樣子を示す。二つの研究室には、被験者 の他に記録者が1人ずつ在室し、気付いたことをノートに記録し たり、被験者がビデオを意識して㗨張しないように気軽に話しか けたりした。

被験者には「暑い」「涼しい」「寒い」「汗が出ている」「汗でべ たつく」「不快」と書かれた六つの札を渡し、室内の熱環境が札に 書かれた温冷感に近いと感じた時に、いつでもいくつでも札を挙 げてもらい、その様子をビデオよって記録した。温冷感が六つ の札のどれにも該当しないときは、札をまったく挙げないように してもらった。また上記六つ以外の温冷感を感じた時には、その 感覚を自由に発言してもらうことにした。被験者は食事をするこ とと席を離れること以外は自由に振舞ってもらったので、実験中 はお喋りをしていたり、読書をしていた。水分は自由に掑っても らうことにした。なお、被験者の行動と発言は、移動中も含めて実 験をしている時間のすべてにわたってビデオ撮影により記録した。

\section{3．通風・冷房か温冷感に与える影䇺}

図 2 に、18日1回目において、通風を行なっている室（以下、 通風室）と、設定温度 $25^{\circ} \mathrm{C}$ で冷房を行なっている室（以下、冷房 $\left(25^{\circ} \mathrm{C}\right)$ 室と表記) の空気温・周壁平均温度の経時変化を示す。通 風室の空気温は $28 \sim 29.5^{\circ} \mathrm{C}$ である。冷房 $\left(25^{\circ} \mathrm{C}\right)$ 室のそれは 22 ～ $26.5^{\circ} \mathrm{C}$ の間で大きく変動している。これらの空気温はともに室 中央部での計測値である。冷房 $\left(25^{\circ} \mathrm{C}\right)$ 室における空気温の変動 は、空調機の $\mathrm{ON}$ - $\mathrm{OFF}$ 制御によって生じている。通風室の周壁 平均温度は約 $29^{\circ} \mathrm{C}$ 、冷房 $\left(25^{\circ} \mathrm{C}\right)$ 室のそれは約 $27^{\circ} \mathrm{C}$ である。周 壁平均温度（以下、MRT）は壁 4 面・床・天井・育の計 7 ケ所で 計測した表面温度の面積加重平均である。相対湿度は通風室で約

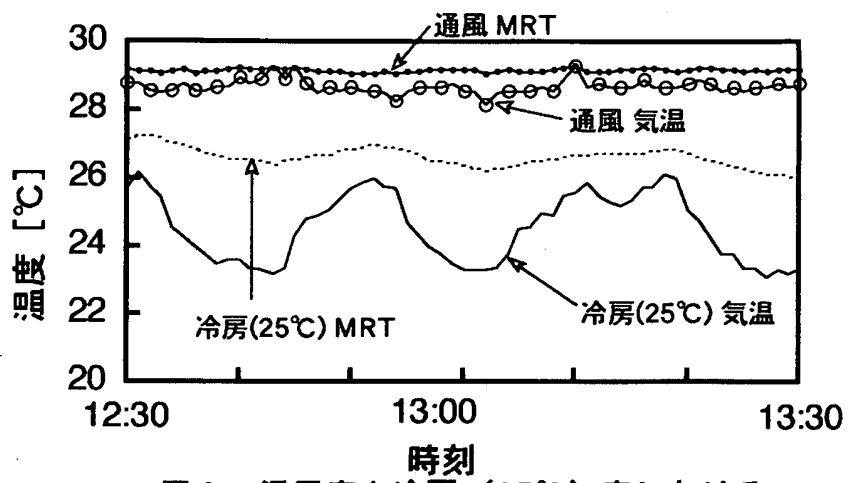

図 2 通風室と命房 $\left(25^{\circ} \mathrm{C}\right)$ 室における 空気温・MRT（18日1 回目）
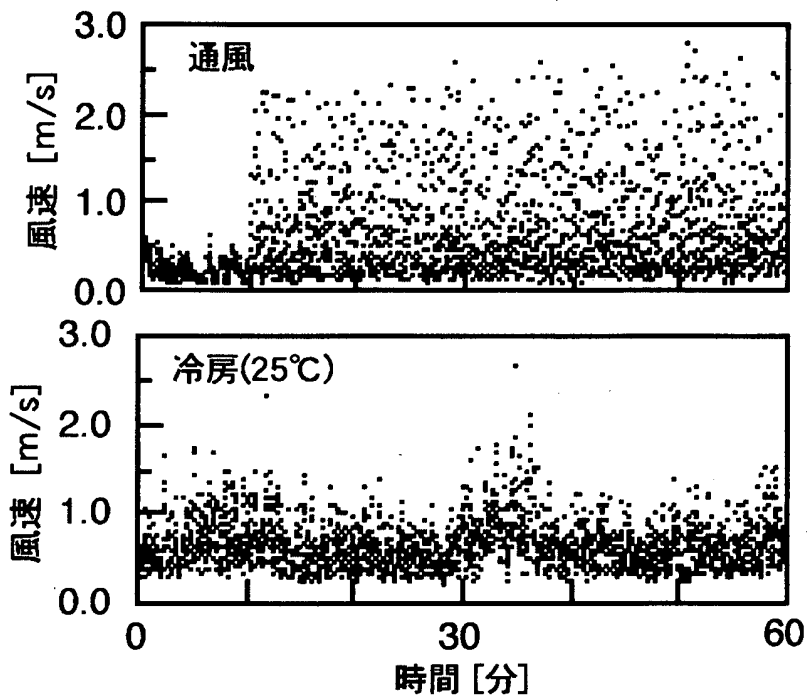

园 3 通風室と冷房 $\left(25^{\circ} \mathrm{C}\right)$ 室における風速（19 日）

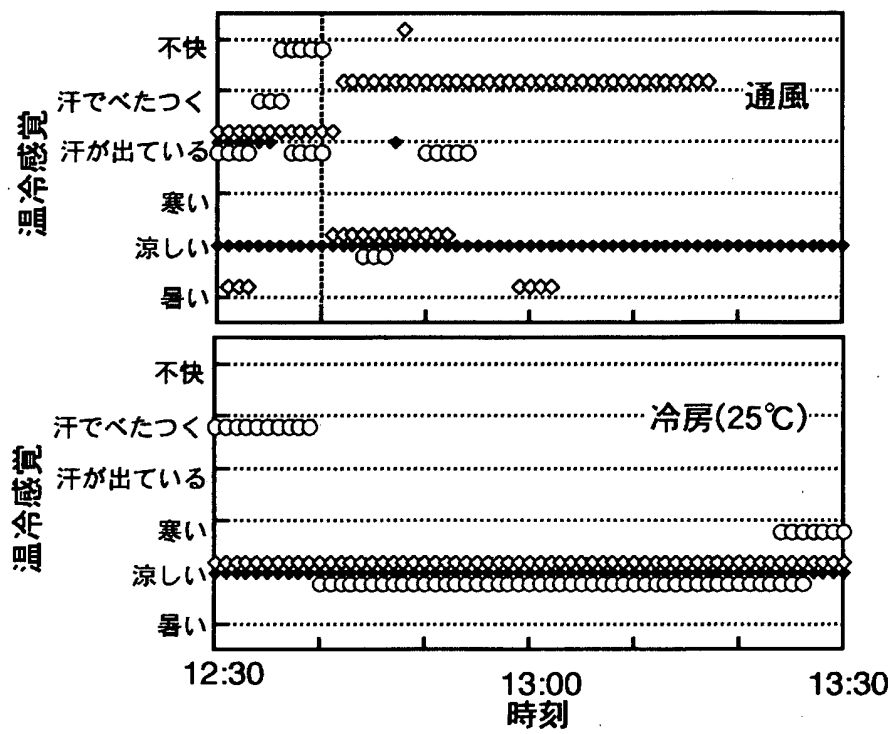

図 4 通風室と泠房 $\left(25^{\circ} \mathrm{C}\right)$ 室ての温冷感申告

$65 \%$ 、冷房 $\left(25^{\circ} \mathrm{C}\right)$ 室で約 $58 \%$ であり、ほほ一定であった。18日 は、風速のデータが久測したので、参考のため図 3 に 19 日 1 回目 における通風室の風速と、19日 2 回目における冷房 $\left(25^{\circ} \mathrm{C}\right)$ 室の 風速を示す。通風室の風速は $0.1 \sim 2.5 \mathrm{~m} / \mathrm{s}$ 、冷房 $\left(25^{\circ} \mathrm{C}\right)$ 室のそ れは $0.2 \sim 2 \mathrm{~m} / \mathrm{s}$ である。通風室の風速が $1 \mathrm{~m} / \mathrm{s}$ 以上になっている 


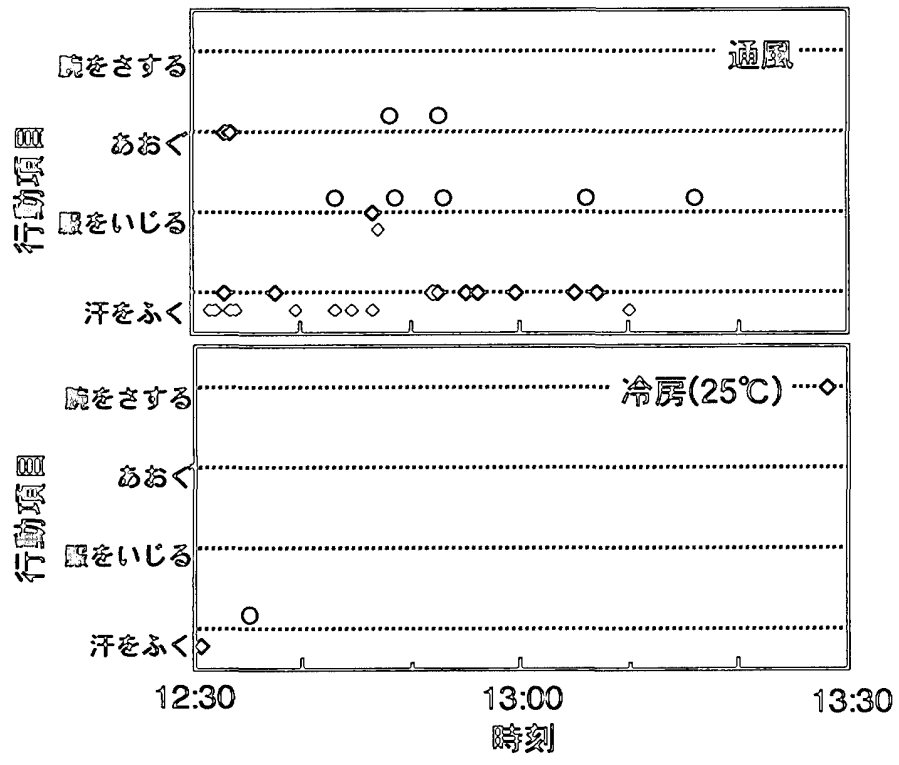

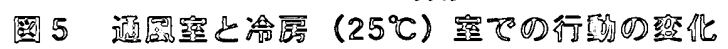

のは、外部からの風に加えて扇風㙨からの風が風速計に当たって いるためである。風速の変動は通風室の方が冷房 $\left(25^{\circ} \mathrm{C}\right)$ 室より 大きい。なお 19 日においても入室 10 分後から扇風機を使用して いる。通風室では、入室 10 分後から扇風機を首振りの状態で使用 した。空から入る風は風速 $0.5 \mathrm{~m} / \mathrm{s}$ 以下であり、扇風機正面にお ける最大風速は約 $2.5 \mathrm{~m} / \mathrm{s}$ であった。扇風僟は首振りの状態で使 用しており、廊下㑡の机の中央に封して座っている被臨者には9.5 秒周期、それ以外の被医者 4 人には 19 秒周期で $0.1 \sim 2.5 \mathrm{~m} / \mathrm{s}$ の 筑囲で変動する気流が当たっていた。

各室における 5 人の申告は、1人、2人、2人のおおむね三つ のパターンに分かれたので、これらのパターンをそれぞれ代表す 万被験者 3 人の申告結果を示すことにした。図 4 は、通風室と冷 房 $\left(25^{\circ} \mathrm{C}\right)$ 室の温冷感申告である。通風室では、○とつの 2 人が、 扇風瀻の風が当たり始めた直後 $(12: 40)$ から「涼しい」を申告 している。1時間を通してみると、最初から最後まで「涼しい」を 申告している人 (つ) もいれば、「汗でべたつく」と感じている人 や、札を挙げずに「涼しくもなければ暑くもない」と発言する人 もいた。このように通風室では、温冷感の個人差が大きく、温冷 感の経時変化がみられる。一方、冷房 $\left(25^{\circ} \mathrm{C}\right)$ 室では、ほほ结全員 が入室直後から退室するまで「涼しい」を申告しており、変化が ほとんどない。冷房 $\left(25^{\circ} \mathrm{C}\right)$ 室の温冷感は、通風室のそれに比べ て、個人差や経時変化が小さいことがその特徵である。

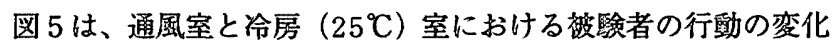
である。なお、例えば図 4 と図 5 の通風（または冷房）のグラフ 中で同一のシンボルは同一被㹂者であることを示している。以下 の図でも同檬である。通風室ではさまざまな行動がとられており、 入室直後から退室 10 分前 $(13: 20)$ までの間、「汗をふく」「服を いじる」「あおぐ」といった行動がとられている。これに対して冷 房 $\left(25^{\circ} \mathrm{C}\right)$ 室での行動は、入室直後に 2 人の被踰者による「汗を

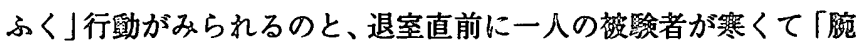
をさする」行動が 1 回みられるのみである。写真 3 は入室 30 分後

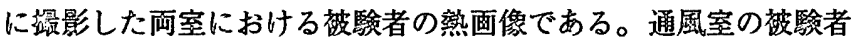

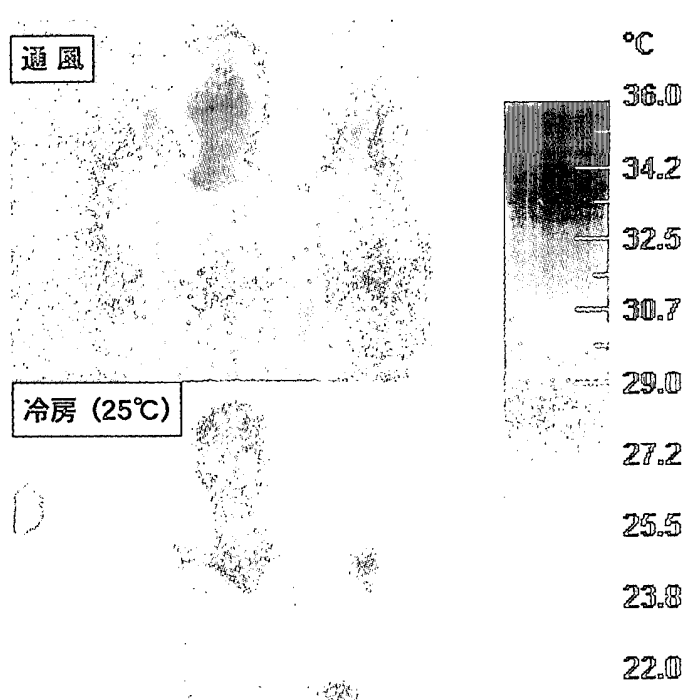

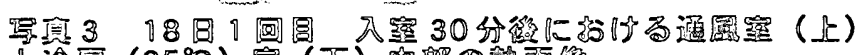

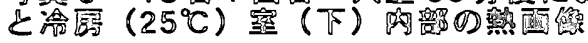

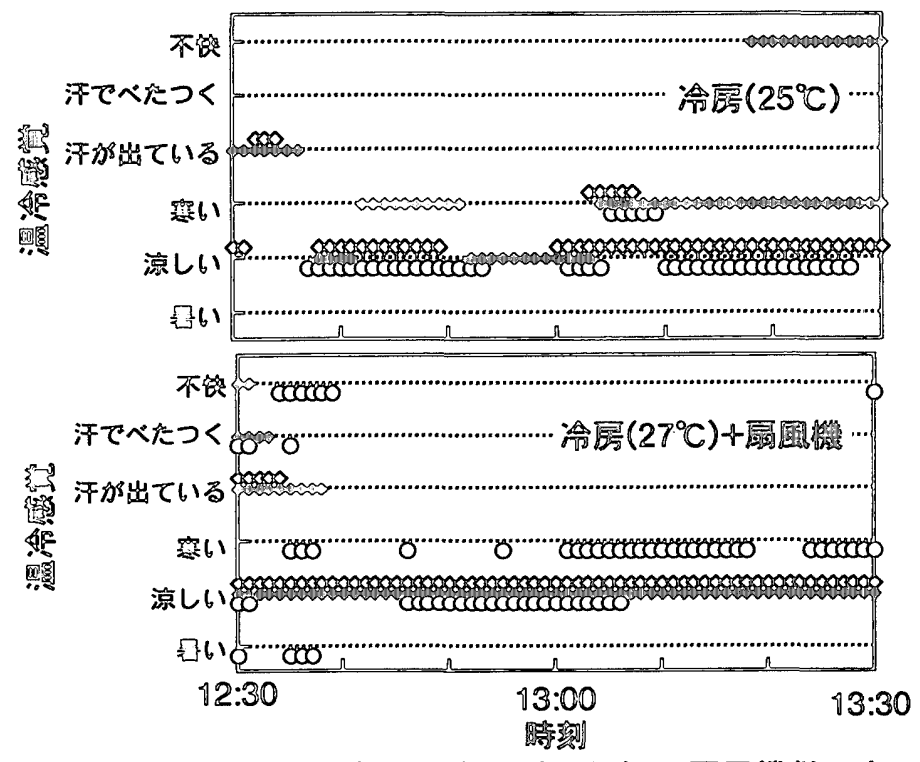

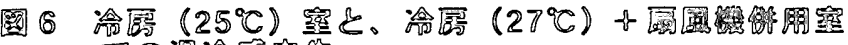

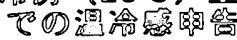

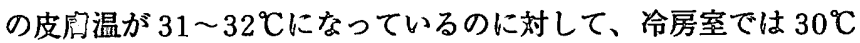
であり通風室より低くなっている。

両室における等徵的な発言を抽出すると、冷房 $\left(25^{\circ} \mathrm{C}\right)$ 室では 「涼しい最高」「涼しい以外他にない」などの発言が目立ち、通風 室では「風が来ると涼しい」「汗が残っている」などの発言が多 かった。通風室、冷房 $\left(25^{\circ} \mathrm{C}\right)$ 室ともに入室直後に汗に関する申 告があるが、通風室では「寒い」が申告されていないのに対して、 冷房 $\left(25^{\circ} \mathrm{C}\right)$ 室では「寒い」が申告されている。

図 6 に冷房 $\left(25^{\circ} \mathrm{C}\right)$ 室と、冷房 $\left(27^{\circ} \mathrm{C}\right)$ 扇風機併用室での温 冷感申告を示す。どちらの室においても被呤者が 1 人ずつ、入室 直後に汗に関する申告をした後、「寒い」を申告し、入室 10 分後 以降に「涼しい」と「寒い」を申告している。札による温冷感の 申告や被匼者の行動と発言において、二つの室に際立った大きな 遠いはない。以上のことから両室の在室者の温冷感にあまり差が ないと考える。 


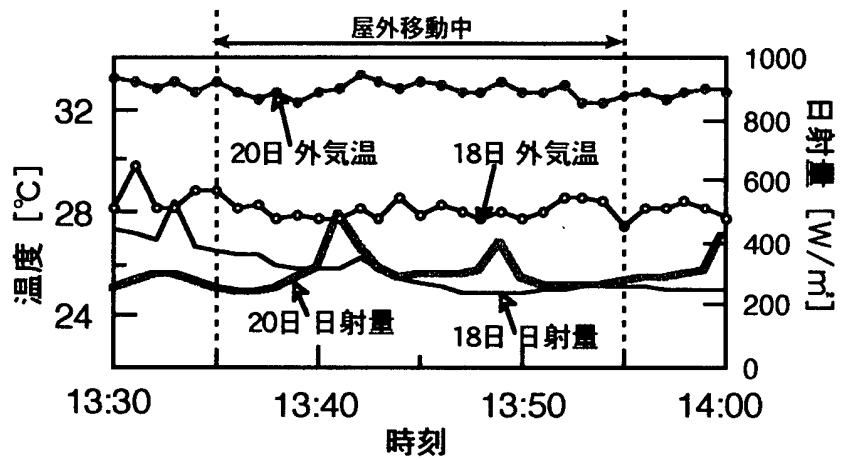

图 718 日・20日における外気温と日射量

\section{3.入室に至るまでの屋外熱環境が温冷感に与える影翌}

2.に述べたように、異なる屋外熱環境を経て室に入る実験を 19日に行なった。しかし、予想に反して被験者が曝露された屋外 熱環境は、二つの経路ともに日射量が $200 \mathrm{~W} / \mathrm{m}^{2}$ 、気温が 25〜 $27^{\circ} \mathrm{C}$ で両者にほとんど差がなかった。そこで、たまたま屋外環境 条件の異なった 18 日 2 回目と 20 日 2 回目の結果を比べることに した。図 7、図 8 はそれぞれ、18日と20日に被験者が屋外を移 動している時間帯において講義研究棟屋上で計測した外気温と日 射量・風速である。18日、20日はともに同じ経路を通って入室 している。外気温は 18 日に平均で約 $28.5^{\circ} \mathrm{C} 、 20$ 日で約 $33^{\circ} \mathrm{C}$ であ り、18 日の方が $4.5^{\circ} \mathrm{C}$ 低い。日射量は平均すると 20 日の方が 18 日よりやや大きい。風速は 18 日で 1.5 $5 \mathrm{~m} / \mathrm{s}$ 、20 日では $1 \sim 5.5$ $\mathrm{m} / \mathrm{s}$ であり、両日においてあまり差がない。これらのことから 20 日の方が18日よりも暑さが厳しいと思われる屋外環境から建物に 入ったと考えることができる。

図 9 は、冷房 $\left(25^{\circ} \mathrm{C}\right)$ 室で実現された空気温・MRT ・ 風速を、 18 日 2 回目と 20 日 2 回目とで比較したものである。空気温・ $\mathrm{MRT}$ ・風速のいずれも、両室においてほほ同様の值である。相対 湿度は 18 日で約 $62 \% 、 20$ 日で約 $64 \%$ であった。以上のことから 再日の室内はほほ同様の熱環境と考える。

図 10 は、18日と 20 日における冷房 $\left(25^{\circ} \mathrm{C}\right)$ 室の温冷感申告 である。18日は、空調機から冷風か吹き出したことによって空気 温が 2 回低下したときに、2 回ともに「寒い」の申告がある。一 方、20日も、空気温が 2 回低下しているが、1 回目の室温低下で は「寒い」が申告されず、2 回目にはじめて「寒い」が申告され ている。入室直後から $14: 10$ までの間は、18 日の室温の方が 20 日より高いにも関らず、18 日の方で入室から 15 分ほど経過した 時点に「寒い」が申告されている。空気温が 1 回目に低下したと きに、18日では「寒い」が申告され、20日では申告されなかっ たことは、両日の室内熱環境の差よりも、20日の屋外熱環境が 18 日のそれより暑かったことが影響した可能性があると考えられる。 写真 4 は 18 日と 20 日における入室直後と 60 分後の被験者の熱 画像である。18日では、皮周温が $30^{\circ} \mathrm{Cから} 29^{\circ} \mathrm{C} に$ 下がっている のに対して、20日では逆に $31^{\circ} \mathrm{C} か ら 32^{\circ} \mathrm{C} に$ 上昇している。20日 において被験者の皮膚温が高くなったのは、暑い屋外熱環境に曝 露されたためと考えられる。両日ともに $14: 30$ 以降では「寒い」 の申告があるので、この時間帯では屋外環境によって生じたほて りの影響がなくなってきていると考えられる。18日、20日のい

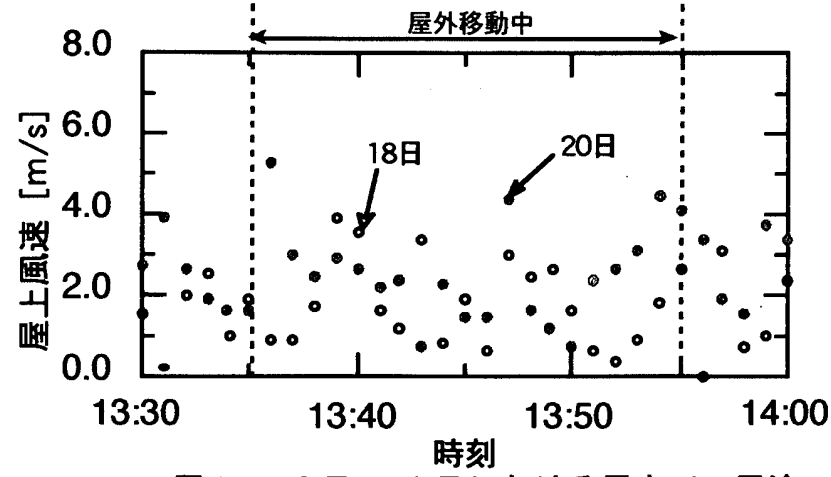

図818日・20日における屋上での風速
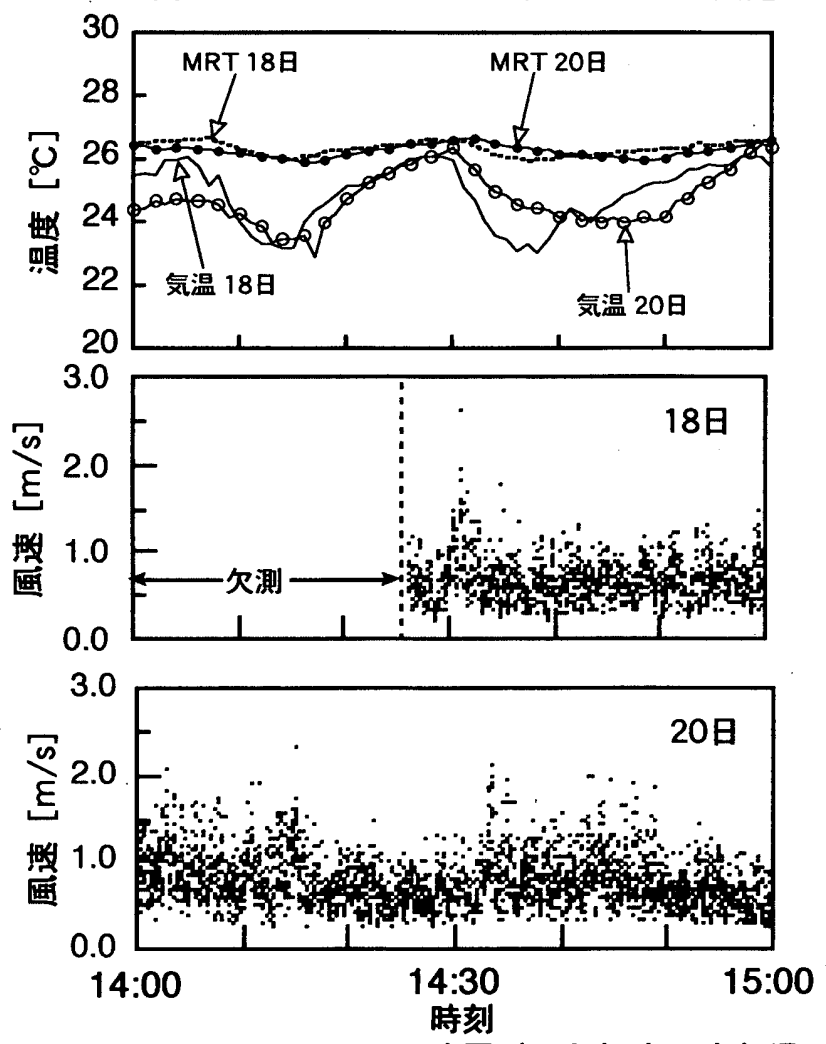

図918日・20日の冷房 $\left(25^{\circ} \mathrm{C}\right)$ 室の空気温 -MRT・風速
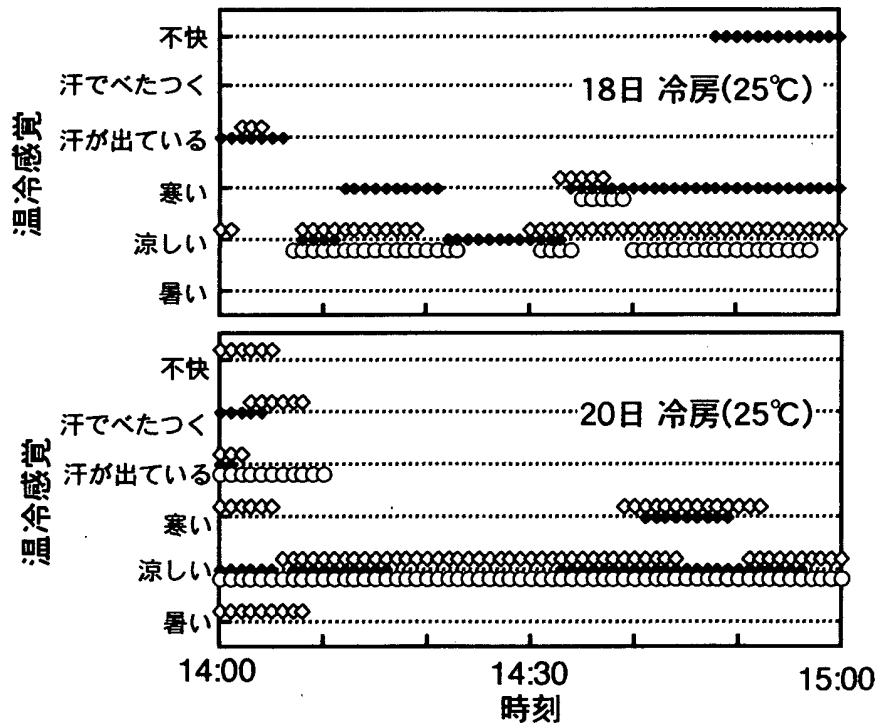

図 1018 日・20日の冷房 $\left(25^{\circ} \mathrm{C}\right)$ 室における 温冷感申告 


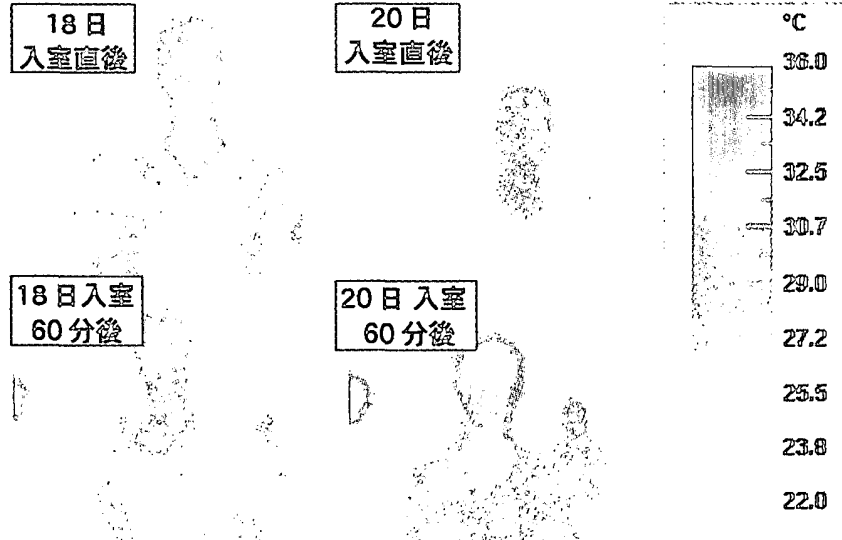

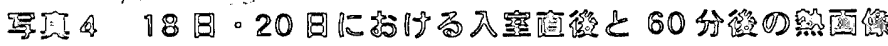
ずれにおいても入室直後に被験者全員が汗に関して申告している けれども、空気温度が下がり始める入室 10 分後 $(14: 10)$ 頃には それらはなくなっている。

以上のことから、入室経路を莟蔍して、木陰などのできるだけ 暑さの爰しくない屋外環境を経て入室すれば、入室直後の冷房設 定温度を過度に低くせずに、不快でない室内懪境をつくりうるこ とが予想される。

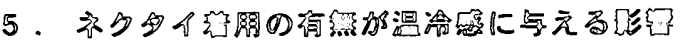

図11は、20日 1 回目における冷房 $\left(25^{\circ} \mathrm{C}\right)$ 室における空気温・

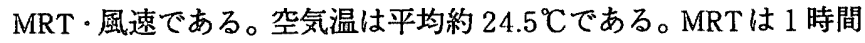
で $27.4^{\circ} \mathrm{C}$ から $26.4^{\circ} \mathrm{C}$ に低下している。なお風速は $0.5 \sim 2.6 \mathrm{~m} / \mathrm{s}$ 、 相封湿度は平均約 $60 \%$ 、吹出し空気温は $17 \sim 19^{\circ} \mathrm{Cであった。}$

図12は、ネクタイ非着用者とネクタイ着用者の温冷感申告であ る。ネクタイ非着用者（男 1 名、女 2 名） 3 名は廊下㑡に、ネク 夕イ着用者 2 名は空㑡に座っている。入室直後は、ネクタイ着用 の有無に関らず、全員が「涼しい」を申告している。ネクタイ非 着用者のつとつは、入室 13 分後から「寒い」を申告し始的ている。 ただし、「涼しい」と「寒い」の双方を申告している。しかし、入 室後 30 分（13:00）を過ぎると「寒い」のみの申告となり、終了 10 分前（13:20）には「不快」を申告している。○も終了 17 分 前 (13:13) 加「寒い」を申告している。一方、ネクタイ着用 者は、空調機のト゚ラフトによって空気温がやや低くなっている空 貸にいるにもかかわらず、1 時間を通してほほ「涼しい」を申告 している。汗の申告をみると、ネクタイ非着用者は、閶始 4 分ほ どで申告が消えるけれども、ネクタイ着用者は、申告が消えるの に約 10 分ほどかかっている。

代表的な発言を抽出すると、ネクタイの非着用者は、「寒い小 「肌寒い感じがする」等の発言が多く、ネクタイ着用者は、「快適 で眠くなってきました」「ちょうど良いです」などの快適であると いう内容の発言が多かった。

図13に、ネクタイ非着用者とネクタイ着用者の行動の変化を示 す。ネクタイ非着用者は、入室後 10 分間に、「汗をふく」の行動 を新回とり、12:40を過ぎると行動の回数が減り、12:50にはそ れはなくなっている。一方、ネクタイ着用者では、「服をいじる」 「汗をふく」「あおぐ」という行動が1時間中絶えずあり、特に始 めの 10 分間にその回效が多い。両者の申告・言動の逪いから、20

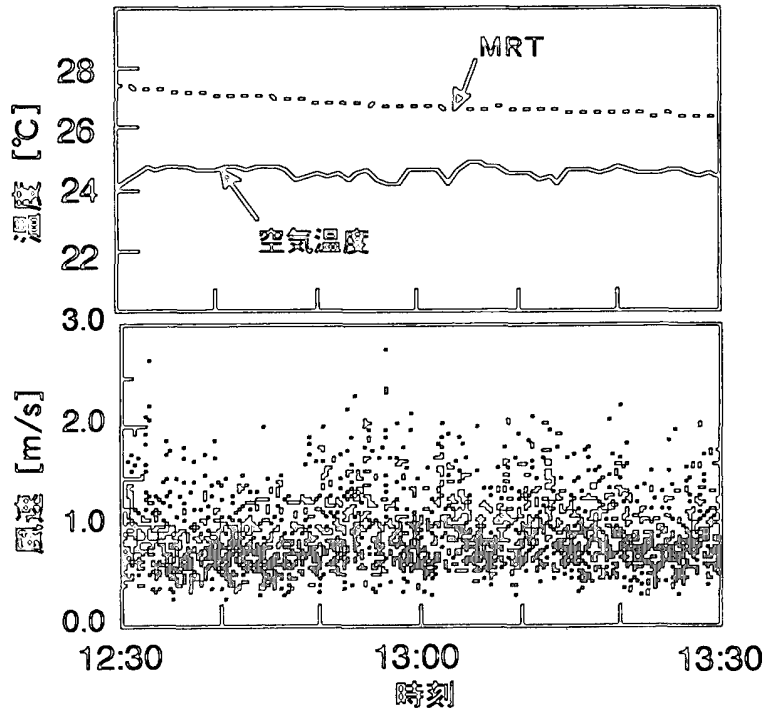

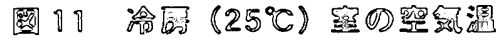

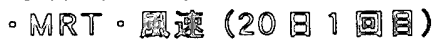

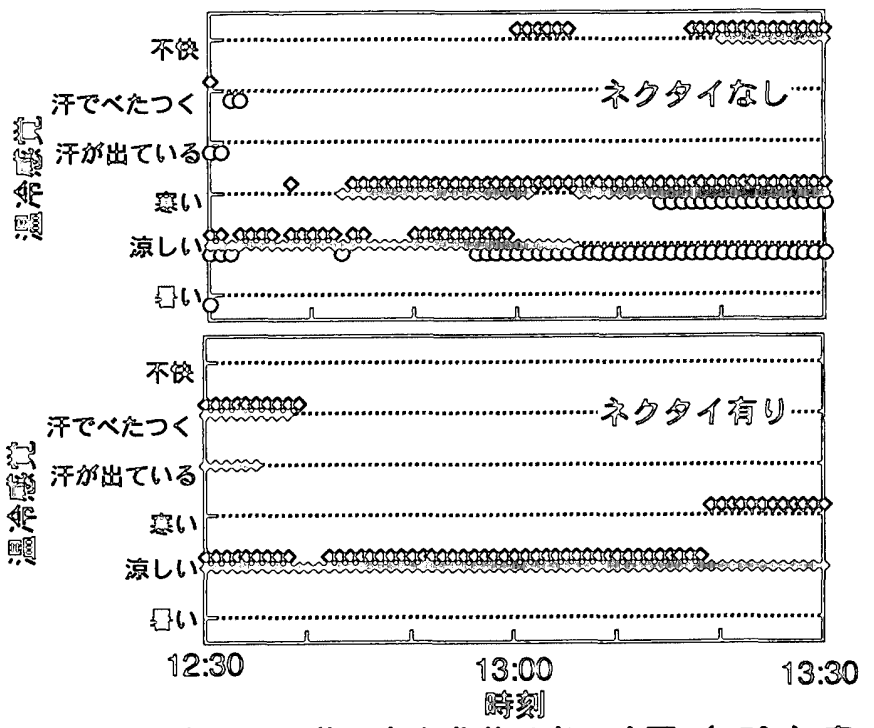

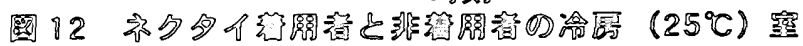

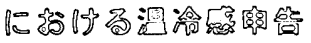

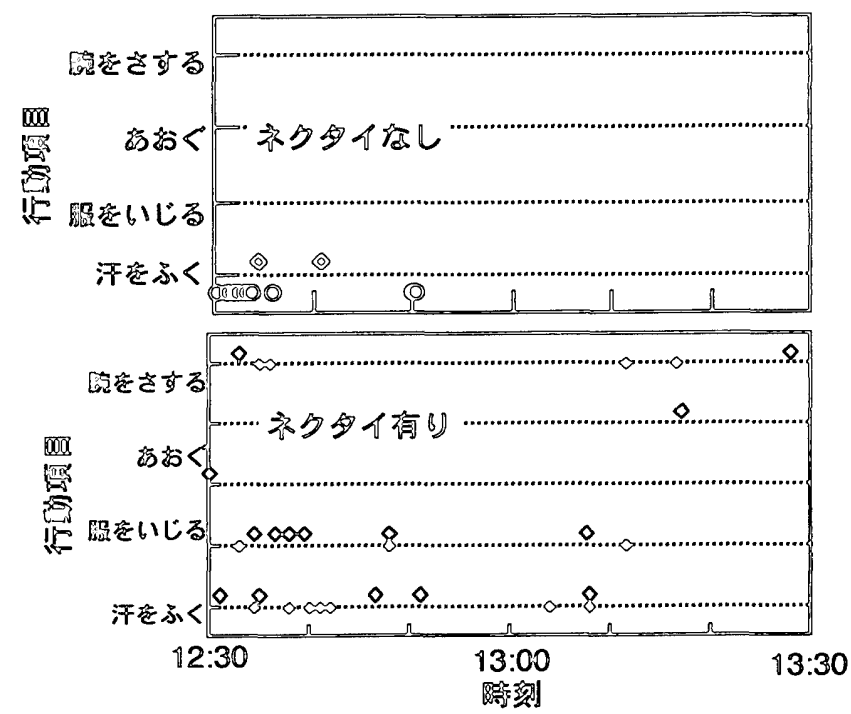

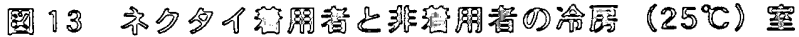

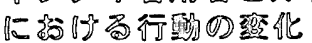



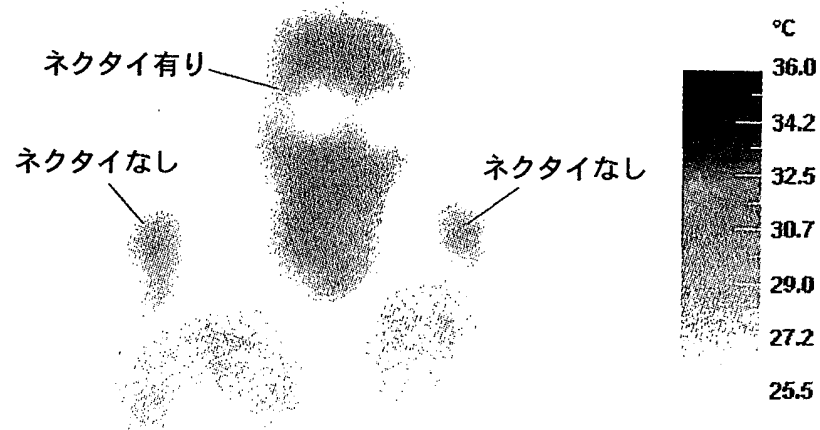

写真 520 日における入室 30 分後の熱画像（前の一人が ネクタイ着用、後ろの二人は非着用)

日における冷房 $\left(25^{\circ} \mathrm{C}\right)$ 室は、ネクタイ着用者にとっては涼しい 環境であっても、ネクタイ非着用者にとっては寒くて不快である。 写真 5 に入室 30 分後における被験者の熱画像を示す。写真中央の

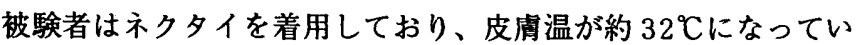
る。一方、中央の被験者の両肩に写っている被験者の顔の皮成温は ネクタイを着用している被験者より若干低くなっている。ただし、 赤外線放射カメラに対する両者の形態係数が大きく異なり、またカ メラの分解能に限界があることからその差は明確とは言えない。

\section{6. おわりに}

自然共生建築における行動をも含んだ暑さの対処法が温冷感に 与える影響を把握することを目的として、被験者の申告と行動を ビデオ撮影により観察した結果、以下のことが明らかになった。

1) 制約条件の少ない被験者実験を行ない、ビデオで被験者の行 動·温冷感を記録することにより、普段の生活により近い状態 での行動・温冷感を把握することができた。このことから、自 然共生建築における熱環境調整のための行動と温冷感の観察方 法の一つが確認できたと考える。

2 ）通風を行なっている室では、風速の変動によって温冷感申告 の個人差と経時変化が大きい。また、「汗をふく」などのさま ざまな行動が入室時から退室10分前まで頻繁にとられていた。 通風室における温冷感の特徴は多様で変動的なことである。

3 ) 設定温度 $25^{\circ} \mathrm{C}$ 冷房室では、空気温の変動が大きいにもかか わらず、温冷感申告の経時変化がほとんどなく、個人差も小さ い。「汗をふく」などの行動はほとんどとられていない。冷房 室における温冷感の特徴は定常的で画一的なことである。

4 )ほぼ同等の温熱環境の冷房室に、暑い屋外熱環境から入室す る場合と、涼しい屋外熱環境から入室する場合とについて温冷 感を比較すると、涼しい屋外環境から入室する場合では「寒 い」が申告されたの対し、暑い屋外環境から入室する場合では 「寒い」が申告されなかった。このことから、木陰などの涼し い入室経路を経て室内に入ると、冷房設定温度を過度に低くし なくても涼しさをもたらすことが可能になると考える。

5 ) 設定温度 $25^{\circ} \mathrm{C}$ の冷房室はネクタイ着用者にとっては涼しい環境 であっても、ネクタイ非着用者にとっては寒くて不快であった。 今後、このような研究を重ねることで、住まい手が住まい手に とって望ましい住まい方を選ふための判断材料が蓄積され、自然 共生建築の住まい方とは何かが明らかになっていくものと考える。

\section{参考文嗝}

1) 宿谷昌則：自然共生建築を求めて、鹿島出版会、1999年 2 月。

2 ）荒谷 登：風土諭、日本建築学会編 新建築学体系 8 自然環境、彰国 社、pp.298-328、1984年。

3 ）荒谷 登：環境・省エネルギーと教育、IBEC、No.114、pp.6-9、 1999年。

4) 岩村和夫：環境共生とエコハウジング、小谷部育子・岩村和夫・卯月 盛夫・延藤安弘 著 共に生きるかたち、建築資料研究社、pp.104 116、1997年。

5 ) 延藤安弘：スマートな個人主義と豊かな共同性、小谷部育子・岩村和 夫・卵月盛夫・延藤安弘著 共に生きるかたち、建築資料研究社、 pp.161-200、1997年。

6）榊原典子・石井昭夫 ·片山忠久 - 西田 勝 - 堤 純一郎 : 通風環境に おける気流知覚に関する実験的研究、日本建築学会計画系論文集、 No.385、pp.1-8、1988年 3 月。

7 ）芥川郁雄・佐々木隆・林 基哉・橋本直樹・荒谷 登・赤木一郎：夏 期の町家にみられる変動気流下での PMV の実测調查一開放系住居の 体感指標に関する研究 その 1 一、日本建築学会北海道支部研究報告 集、No.60、pp.13-16、1987年 3 月。

8 ) J. F. Busch (1992), A Tale of Two Population: Thermal Comfort in Air-Conditioned and Naturally Ventilated Offices in Thailand, Energy and Buildings, Vol.18, pp.235-249.

9 ）石野久霖・佐々木元康・有田恒之・石田秀一：空間移動における温熱 感の非定常応答、空気調和・衛生工学会学術講演会講演論文集、 pp.1171-1184、1990年10月。

10) K. Jitkhajornwanich and A. C. Pitts (1998), Thermal Comfort in Indoor and Outdoor Transitional Spaces of Buildings in Bangkok, Proceedings of The Fifteenth International PLEA Conference, pp.357-360.

11）長谷部礼子・林 立也・堀川 晋・田辺新一・木村建一：屋外加屋 内に連続する空間における温熱感の研究一その 1. 移動計測カートを 用いた空港旅客ターミナルでの実測—、日本建築学会大会（近幾）学 街講演会梗概集 D-2 環境工学 II、pp.351-352、1996年 9 月。

12）斉藤雅也・篠原利光・宿谷昌則：パッシブ手法を用いた事務所建築に おける温熱環境の実測—その 1 . 冷房設定温度と温冷感一、日本建築 学会大会 (関東) 学術講演会梗概集 D-2 環境工学 II、pp.485-486、 1997年 9 月。

13) S. Tanabe (1997), Importance of Clothing For Passive Cooling Effect, Proceedings of The Fourteenth International PLEA Conference, Vol.3, pp.9-14.

14）撶野麻衣子・神林加代子・高橋 達・宿谷昌則：換気手法の違いが室 内の温熱環境に与える影響に関する実測一その 1 . 換気手法別の室温 の比較一、日本建築学会大会 (九州) 学術講演会梗概集 D-2 環境工学 II、pp.485-486、1998年 9 月。

15）蟻川洋祐・杉岡弘朗・松岡弘幸・高橋 達・斉藤雅也・宿谷昌則：暑 さへの対処方法が個人の温冷感覚と行動に与える影響に関する研究— その 1 . 実験方法の概要と通風・冷房の影帮一、日本建築学会大会（中 国）学術講演会梗概集 D-2 環境工学 II、pp.455-456、1999年 9 月。

16）杉岡弘朗・蟻川洋祐・松岡弘幸・高橋 達・斉藤雅也・宿谷昌則：暑 さへの対処方法が個人の温冷感覚と行動に与える影響に関する研究— その 2. 入室に至るまでの屋外熱環境と着衣の影㤎一、日本建築学会 大会（中国）学術講演会梗概集 D-2 環境工学 II、pp.457-458、1999 年 9 月。

注 1$)$ 本論文では、パッシブ建筑、環境共生建築、エコロジー建築と通 常呼ばれる建築をすべて自然共生建筑と呼ふことにする。具体的事例とし ては、世田谷区墚沢環境共生住宅、東京ガス港北NTビル、武蔵工業大学横 浜キャンパス（環境情報学部）などが挙げられる。

注 2） 本論文は既に発表した文献15）16）をまとめて加筆修正したもの である。

\section{辢辞}

本研究を進めるにあたり、武蔵工業大学 横浜事務室の佐々木暢俊氏をは じめ同大学の教職員・学生の方々、宿谷研究室の大学院生 湯沢映子氏に多 大なご支援をいただきました。ここに記して感謝いたします。

（1999年 4 月 26 日原稿受理，1999年12月 9 日採用決定） 